\title{
ЖИТИЈЕ СВЕТОГ ИРИНЕЈА СИРМИЈСКОГ У ЕТИОПСКОМ СИНАКСАРУ
}

Сажетак: у раду се анализира кратко житије Светог Иринеја, првог историјски потврђеног епископа Сирмијума, које је записано у једном етиопском синаксару. Ово је житије потпуно непознато нашој стручној јавности, а ни у другим земљама стручњаци који се баве овом тематиком није коришћено при анализи живота и страдања овог сирмијског епископа. У раду ће бити преведено ово житије и дати неопходни коментари, са акцентом на могуће изворе за његов настанак, као и на анализу структуре самог помена страдања сирмијског епископа Иринеја у етиопском синаксару.

Кључне речи: Свети Иринеј, Сирмијум, етиопски синаксар.

У црквеној књижевности, посебно оној средњовековној, синаксар означава збирку краћих, пролошких, житија светаца поређаних за сваки дан у години. Термин

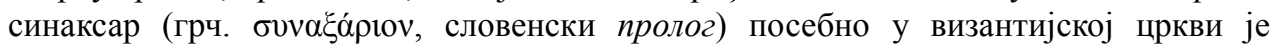
означавао и често компилацију кратких пролошких хагиографских белешки, односно пролошких житија. Најпознатији византијски синаксар је настао у доба цара Василија II Бугароубице у X веку, али их има наравно још доста, и то у свим хришћанским земљама. ${ }^{1}$

Један посебно занимљиви синксар је у центру наше пажње овом приликом. Ради се о етиопском синаксару у коме се, поред многобројних житија, налази и једно

\footnotetext{
* Текст је настао као фазни резултат рада на пројекту Војвођански простор у контексту европске историје (број 177002) Министарства просвете, науке и технолошког развоја Републике Србије и као фазни резултат рада на пројекту Средњовековна насеља на тлу Војводине. Историјски процеси и догађаји (број 114-451-2216/2011) Покрајинског секретаријата за науку Владе Аутономне покрајине Војводине.

${ }^{1}$ Из богате литературе издвајамо неколико кључних дела са основним подацима о синаксару односно месецословима уопште: Н. -G. Beck, Kirche und theologische Literatur im byzantinischen Reich, München, 1959, 251-252, уп. нап. 3; Ђорђе Трифуновић, Азбучник српских средњовековних књижевних појмова, Београд, 1990, 317-321 са обимном библиографијом; The Oxford Dictionary of Byzantium, волуме 3, ed. by Alexander Kazhdan, Oxford, 1990, 1991 са библиографијом; Rečnik književnih termina, gl. i odg. ur. Dragiša Živković, Beograd, 1992, 470, 776 (аутор обеју одредница и минологиј и синаксар, Димитрије Богдановић); Дејан Михаиловић, Византијски круг, Београд, 2010, 179; Tanja Popović, Rečnik književnih termina. Drugo izdanje, Beograd, 2010, 424.
} 
кратко, пролошко житије Светог Иринеја, првог историјским изворима потврђеног епископа града Сирмијума. На почетку ћемо, стога, рећи неколико уводних напомена о самом издању овог синаксара, као и о етиопском календару уопште, као и о синаксару који нам је послужио као извор за ово житије. Након тога, биће дат етиопски оригинал, као и превод овог житија, који ће бити праћени неопходним коментарима и анализом.

Што се издања овог синаксара тиче, он је објављен у неколико верзија. Још 1928. године Волис Баџ, вероватно један од најбољих познавалаца древног Египта издао је четворотомни етиопски минологиј, заснован на два рукописа из Британског музеја. Рађен је, додуше, само на два рукописа, што не умањује вредност овог прилично великог труда. Ово издање има и додатке у виду спискова патријараха, цариградских, затим јакобитских, мелкитских, александријских, антиохијских, као и листу римских папа. До данас најбоље и најпотпуније критичке верзије овог етиопског синаксара, засноване на неколико манускрипата јесте у чувеној едицији Patrologia Orientalis. Рене Графен, оснивач и први уредник ове волуминозне едиције је још 1897. Ињацију Гвидију, чувеном италијанском оријенталисти и професору на Римском универзитету предложио издавање етиопског синаксара. Штавише, први том Patrologia Orientalis садржи неколико уводних страница Ињација Гвидија и издање синаксара за месец сане. Он је започео овај подухват на основу три рукописа овог синаксара. Осим њега за издавање овог синаксара био је заслужан још један велики стручњак за Етиопију Силван Гребо, важан и за текст којим се бавимо. Жерар Колен је учинио понајвише на савременом критичком издању већег дела синаксара, којим се бавио 80-их година прошлог века и тренутно је несумњиво највеће име међу истраживачима овог синаксара. Најстарији рукопис потиче из XV века и налазио се у библиотеци чувеног истраживача Етиопије Антоана д'Абадија. Што се друга два манускрипта тиче један се налази у париској Националној библиотеци, а други у Оксфорду, у Бодлијевој библиотеци. Оба потичу из XVIII века, вероватно из периода 1730-1755, односно из доба владавине Ијасуа (Јошуе) II. Овај првопоменути рукопис је у ствари превод са арапског на гиз, док и у друга два ce осећају утицаји арапских синаксара, али текстом донекле одступају од д'Абадијевог манускрипта. Овим нововековним рукописима најсличнији су и сви остали познати рукописи етиопског синаксара. То нису једина издања овог синаксара. Изгледа да су неке арапске рецензије потицале чак и са краја XIV столећа, за једну се зна да је настала 1383-1392, док је први потпуни рукопис синаксара из периода између 1563. и 1581. године. Овај други синаксар је са знатно мање коптских утицаја и арабизама, који су били доминантни у средњовековним рукописима. У раним рецензијама, попут д'Абадијевог рукописа налази се и много података о старохришћанском Египту, док у каснијим рукописима расте број информација које се односе на Етиопију. За нашу тему, односно издање синаксара за месец нехасе у ком се налази пролошко житије Светог Иринеја, важно је рећи да се заснива на прва три поменута манускрипта-д'Абадијевом, оксфордском и париском. ${ }^{2}$

\footnotetext{
${ }^{2}$ Le synaxaire éthiopien Les mois de sanê, hamle et nahasê. I mois de sanê, Publiés et traduiits par Ignazio Guidi, traduits en français par Sylvain Grébaut, Patrologia Orientalis, tome I, Paris, 1907, 523-525; Gérard
} 


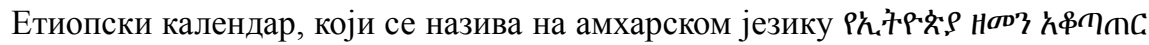

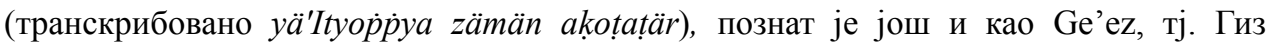
календар, према језику на ком су названи месеци у години, главни је календар који се користи у Етиопији, а такође и у литургијске сврхе различитих хришћанских цркава и деноминација у Еритреји. Заснован је на александријском, односно коптском календару, који потиче од старог египатског календара. Већина коптских месеци и носе староегипатске називе. Као и код јулијанског календара, свака четврта година је преступна. Година почиње 29. или 30. августа по јулијанском календару. Разлика од седам или осам година између етиопског и грегоријанског календара потиче од разлике у календару. Наиме, Етиопска тевахедо црква се држи старог александријског календара, који у односу на календар Дионисија Малог ствара разлику од седам-осам година. Као и код коптског или старог јерменског календара, година има 12 месеци од по 30 дана, плус пет или шест тзв. епагоменалних дана, који се обично називају тринаести месец. Месеци почињу истим данима као и коптски, само што су имена другачија, на језику Гиз или Ге'ез који је и данас литургијски језик Етиопске православне тевахедо цркве. Шести епагоменални дан се додаје сваке четири године 29. августа по јулијанском календару, шест месеци пре јулијанског преступног дана. Тако први дан етиопске године, 1. маскарам (назива се енкотаташ), пада у ствари по грегоријанском календару на 11. септембар, односно 12. септембар пред јулијанску преступну годину. ${ }^{3}$

Месец нахасе, односно Nähase (етиопски һ九ふ) одговара коптском месецу мисра, или месори/месоре. Ради се о периоду од 7. августа до 5. септембра. Назив овог месеца потиче из староегипатског Mes-en-ra што означава paђaњe Cyнuа, тј. рођење бога Ра. У календару древних Египћана ово је био месец који је био посвећен жетви. ${ }^{4}$

Дан када се, према етиопском календару, прославља Свети Иринеј, епископ Сирмијума, је 29. нахасе, односно 23. август (грегоријански 5. септембар). Пре него што почнемо са разматрањем самог житија, прво доносимо оригинални етиопски синаксарског пролошког житија Светог Иринеја Сирмијског: ${ }^{5}$

\footnotetext{
Colin, Le synaxaire éthiopien. Index généraux, annexes, Patrologia OrientalisTurnhout, 1999, 5-10.

${ }^{3}$ Основне податке о коптском календару из кога се развио и етиопски даје The Coptic Encyclopedia, volume 2, Aziz S. Atiya (editor in chief), New York, 1991, 433-436 са додатном литературом на 436.

${ }^{4}$ Из обиља литературе о староегипатској култури, а у вези са календаром упућујемо читаоце на дело Marshall Clagett, Ancient Egyptian Science, volume II Calendars, clocks, and astronomy, Philadelphia, 1995, 148, посебно о месецу месоре уп. 196-197, 206-211. О месецу месоре писао је пре више од једног века Alan A. Gardiner, Mesore as First Month of the Egyptian Year, in: Zeitschrift für ägyptische Sprache und Altertumskunde 43, 1906, 136-144. Уп. још и Leo Depuydt, Civil Calendar and Lunar Calendar in Ancient Egypt, Leuven, 1997, passim.

${ }^{5}$ Преузето из: Le synaxaire éthiopien III. Les mois de nahasê et de paguemên. Édités par Ignazio Guidi, traduits en français par Sylvain Grébaut, Patrologia Orientalis, tome IX, fascicule 4, № 44, Turnhout, 1981 (репринт издања из 1943), 417-418.
} 


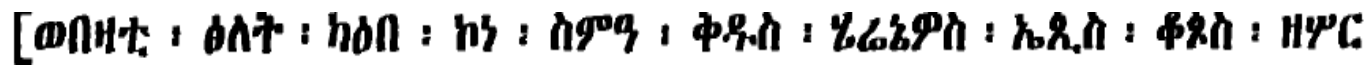

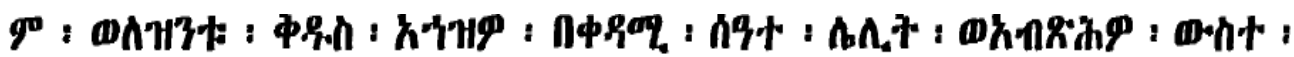

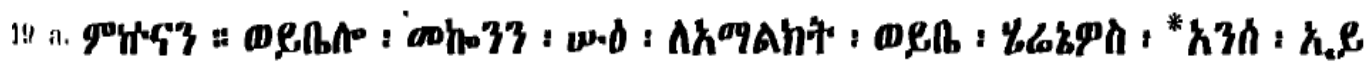

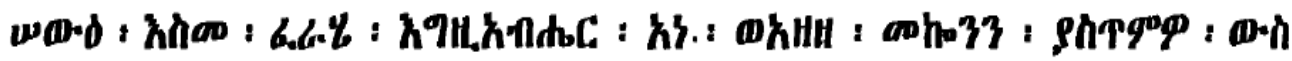

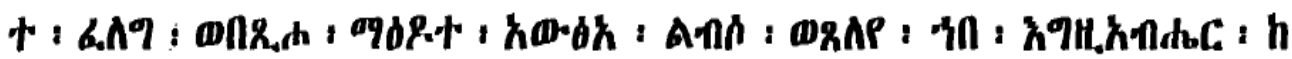

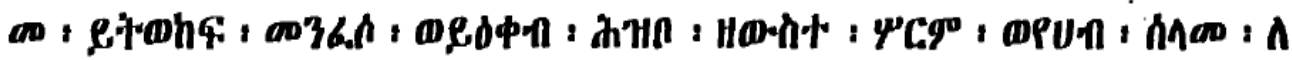

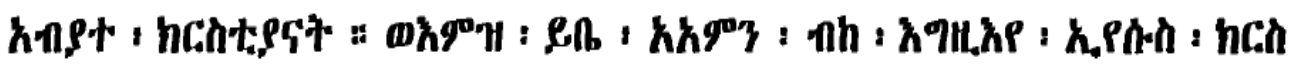

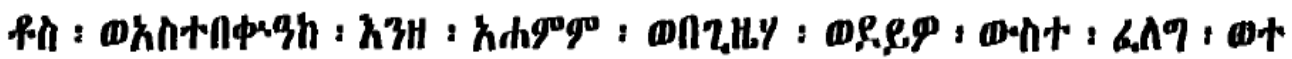

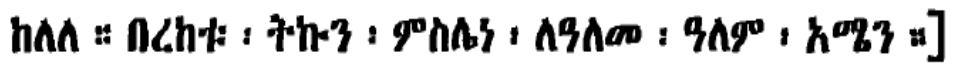

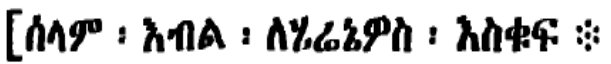

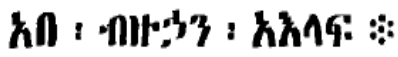

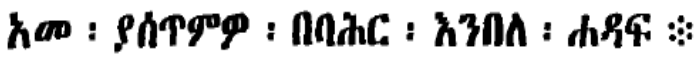

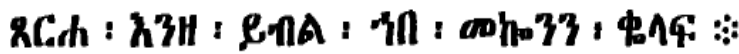

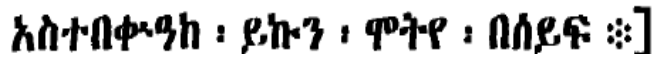

У наставку доносимо његово житије у преводу. Коментари што се тиче језика и стила, превасходно везани за њихово прилагођавање литургијском језику се налазе у фуснотама. Други коментари, везани махом за датум када се прославља, као и за само житије и његов однос према познатим верзијама пасије Иринеја Сирмијског су у наставку: ${ }^{6}$

\footnotetext{
На овај дан такође је ${ }^{7}$ мученик Свети Иринеј, епископ Сорема. ${ }^{8}$ Затворили су га првог часа у ноћи и звели пред суд. Судија му је рекао: принеси жртву боговима! Иринеј је рекао: Ја не приносим жртве, јер се ја бојим Господа. Судија нареди да га потопе у у реку. Пошто је доспео на другу страну реке ${ }^{10}$, скинуо је одећу и помоли се Господу да прими његову душу, да чува народ који живеше у Сирмијуму и да да мир својим ирквама. још је рекао: Верујем у тебе Господе мој Исусе Христе, и призивам Те и преклињем Те, (и) док страдам! Одмах потом, беше бачен у реку и овенчан. ${ }^{11}$
}

\footnotetext{
${ }^{6}$ Преведено према Le synaxaire éthiopien III. Les mois de nahasê et de paguemên, 417-418.

${ }^{7}$ Свакако бисмо пре рекли се такође прославља.

${ }^{8}$ Оставили смо оригинални облик који се доноси у житију, свакако је у питању Срем.

${ }^{9}$ Можда је више у духу нашег језика рећи бачен је у реку.

${ }^{10}$ Изгледа да је у питању грешка преписивача, да се ради о томе како је доведен на обалу реке, или мост.

${ }^{11}$ Мисли се на мученички венац. У оригиналу, а и француском преводу, стоји буквално крунисан, али је
} 
Нека буде његов благослов на нама ${ }^{12}$ у векове векова. Амин!

Поздрављам Иринеја,

Оиа многих хиљада,

Док су га бацили у реку без весла, ${ }^{13}$

Крикнуо је, говорећи необрезаном судији ${ }^{14}$

Молим те, нека моја смрт буде од мача!

Најпре треба свакако рећи нешто о датуму. У синаксару цриградске цркве под овим датумом спомиње се и Свети Иринеј Сирмијски, али и Свети Иринеј Лионски, што није једини случај бркања ове двојице истоимених светитеља, односно навођења обојице као страдалника у исти дан. Грчка православна црква их и слави заједно. Поклапањем њихових имена, али и датума под којим се славе у грчкој цркви, сирмијски епископ је и у етиопски синаксар стављен под датумом пострадања и другог значајног борца за веру - Иринеја Лионског. ${ }^{15}$

У самом Иринејевом житију, односно овом пролошком житију из етиопског синаксара, спомиње се да је ухваћен јер је хришћанин, а потом испитиван од стране Проба, односно судије, како етиопски писац каже. Што се хватања усред ноћи тиче, његова пасија (односно највећи део рукописа, али се у томе слажу све рецензије) наводи, да је после испитивања, био бачен у тамницу и мучен. Када је други пут доведен пред суд, изведен је усред ноћи пред Проба. Вероватно због потребе скраћивања житија за литургијске сврхе, оно је скраћено на овом месту. Пробово име се у етиопском синаксару не спомиње, наводи се само судија, а испитивање, које је у Иринејевом житију, односно у готово свим верзијама његове пасије најважнији део, сведено је. И латинска и грчка верзија страдања сирмијског епископа највећи део текста посвећују управо разговору Проба и Иринеја. Штавише, у науци се данас сматра да је тај део аутентичан и да представља један од најбољих примера ислеђивања при персекуцији хришћана у великом прогону под Диоклецијаном и

више у духу црквеног, односно литургијског језика користити термин који смо и написали у нашем преводу.

${ }^{12}$ Иако у оригиналу стоји са нама, овакав превод је више у духу језика цркве и литургијске праксе.

${ }^{13}$ Сама конструкција је мало незграпна, циља се несумњиво на то да је бачен у реку без могућности да се спасе, односно да преплива. И у самом житију наилазимо на контрадикцију, јер се спомиње да је бачен у реку, али да је доспео на другу страну и бачен у њу, изгледа поново. Очигледна грешка преписивача.

${ }_{14}$ Више него занимљива синтагма. Очигледно се паганима, тј. незнабошцима сматрају необрезани. Коптска, као и Етиопска православна црква су сачувале доста раних хришћанских обичаја, међу којима је и обрезање дечака. В. The Coptic Encyclopedia, volume 4, Aziz S. Atiya (editor in chief), New York, 1991, 1106.

${ }^{15}$ Hippoliti Delehaye, Synaxarium ecclesiae Constantinopolitanae, Propylaeum ad Acta Sanctorum Novembris, Bruxellis, 1902, 917 где се помиње и Свети Иринеј Лионски под 23. августом. Изгледа да забуна потиче још из Василијевог минологија из X века, у коме се страдање овог сирмијског епископа помиње двапут, први пут у марту (када се и иначе прославља), а други пут у августу, као и у етиопском синаксару, уп. Menologii anonymi Byzantini saeculi $X$ quae supersunt. Fasciculus prior, februarium et martium menses continens : sumptibus Caesareae Academiae Scientiarum e Codice Mosquensi 376 Vlad, edidit Basilius Latyšev, Petropoli, 1911, 281-283; Menologii anonymi Byzantini saeculi X quae supersunt. Fasciculus alter, menses iunium, iulium, augustum continens: sumptibus Caesareae Academiae Scientiarum e Codice Mosquensi 376 Vlad, edidit Basilius Latyšev, Petropoli, 1912, 310-311. За друге примере његовог страдања, као и збрку око датума уп. и François Halkin, Bibliotheca hagiographica Graeca, Tome I, Aaron-Ioannes Baptista, Bruxelles, 1957, 41 (бр. 948-951b). 
његовим савладарима. Посебно је занимљиво да писац пролошког житија у етиопском синаксару не помиње разговор епископов са породицом која је, како стоји у скоро свим рецензијама рукописа његове пасије, покушала да га убеди да се одрекне својих веровања. Што се његовог страдања, односно смрти тиче, сирмијски епископ је, према пасији, тј. устаљеној верзији о његовом страдању, посечен мачем и бачен у реку са Артемидиног моста (pons Basentis). Овде се то не спомиње, нити се наводи да је бачен у Саву. На том мосту је и скинуо одећу, завапивши Богу, а не на обали, како етиопски синаксар наводи. Затражио је од Бога да утврди у вери народ (у неким верзијама се и наводи сримијски народ), што даје аналогију са наводом у синаксару да је молио заштиту грађана Сирмијума. ${ }^{16}$

Нажалост, смрт првог сирмијског епископа нема изгледа много везе са пострадањем Иринеја Лионског, о чијој се смрти не зна ништа, сем претпоставке да је и он пао као жртва прогона хришћана, али под римским царем Септимијем Севером, негде око 202. године. ${ }^{17}$ То значи да мотив није преузет из житија Светог Иринеја из Лиона, и да није дошло до збрке на начин као што је дошло у вези са датумом. Тако да можемо све погрешке у односу на стандардан текст страдања Иринеја Сирмијског подвести као превиде преписивача.

Тешко је пратити извор за ово синаксарско житије Светог Иринеја. Вероватно је да је за основу послужио неки грчки, тј. византијски минологиј. У Синаксару који је пронађен у Цариграду, али и у чувеном Василијевом минологију из $\mathrm{X}$ века, у делу који помиње оба Иринеја (дакле у августу), страдање сирмијског епископа је врло кратко. Штавише, оба византијска синаксара дају у августу још краће пролошке белешке о Светом Иринеју из Сирмијума, него овај етиопски синаксар. Помиње се да је епископ и светеномученик из Срема, у Панонији. Наводи се да га је мучио и испитивао Проб и да је Иринеј бачен у Саву. ${ }^{18}$

С обзиром на све то, могуће је претпоставити да је основа било синаксарско житије из неког од византијских минологија. С обзиром на изузетно кратку форму страдања првог сирмијског епископа, вероватно је преузето из неког минологија за август месец. Добро је познато да је управо грчка традиција спојила двојицу истоимених епископа. На тај начин је и писац овог синаксара могао да преузме и прилагоди житије сирмијског епископа за своје потребе, односно за овај синаксар.

\footnotetext{
${ }^{16}$ До данас најкомплетнији текст пасије дао је François Dolbeau, Le dossier hagiographique d'Irénée, évêque de Sirmium, Antiquité tardive, 7, 1999, 205-214, житије на латинском, са преводом на француски (211-214). Овај француски аутор је консултовао велики број манускрипата пасије Светог Иринеја; од српских издања, која се темеље углавном на тексту из Acta Sanctorum, уп. Јустин Поповић, Житија светих за месеи март, Београд, 1973, 481-485; Милена Милин, Пасија Св. Иринеја сирмијскога, Sirmiuт и на небу и на земљи, (1700 година од страдања хришћанских мученика), Сремска Митровица, 2004,185-187. Превод Јустина Поповића јесте архаичан, али у неколико и бољи од превода Милене Милин, чији превод инсистира на савременом српском језику, чак и где се не уклапа. Значајан преглед са набрајањем великог броја различитих верзија страдања сирмијског епископа дао је и Anton Benvin, Muka Sv. Ireneja srijemskoga. Ranokršćanski portret biskupa-mučenika, Diacovensia, 1, Đakovo, 1994, 82-109. Он је сабрао и доста историографских дела на ову тему, чак и неке шпанске рукописе је навео. Ту се налази и солидан превод латинске верзије страдања Светог Иринеја на хрватски језик.

${ }^{17}$ Rosemary Ellen Guiley, The Encyclopedia of Saints, New York, 2001, 157.

${ }^{18}$ H. Delehaye, нав. дело, 917; Menologii anonymi Byzantini saeculi X quae supersunt. Fasciculus alter, 310311.
} 
Свети Иринеј Сирмијски је унет у синаксар етиопске цркве можда због тога што су коптски хришћани дуго рачунали године по тзв. Anno Martyrum односно Epu мученика, или Диоклецијановој ери. То је ера која обухвата велики прогон хришћана под овим римским императором. Како је у његово време пострадао и Свети Иринеј из Сирмијума, не би требало одбацити могућност да је зато унет у етиопски синаксар. Као страдалник из времена највећег погрома над хришћанима био је много значајнији од свог имењака, такође свеца, Иринеја из Лиона.

Кратко пролошко житије Светог Иринеја Сирмијског у етиопском синаксару је веома занимљив показатељ култа ранохришћанског епископа и мученика из Сирмијума који је обухватио и неке најудаљеније, али по важности, без сумње најзначајније древне хришћанске земље.

\title{
BORIS STOJKOVSKI
}

\section{THE LIFE OF SAINT IRENAEUS OF SIRMIUM IN THE ETHIOPIAN SYNAXARIUM}

\begin{abstract}
Summary
This paper analyses the brief hagiography of Saint Irenaeus, the first historically verified bishop of Sirmium, which was recorded in an Ethiopian synaxarium. This hagiography is completely unknown to our professional community, and it has not even been used in analyses by foreign researchers exploring the topic of the life and suffering of this bishop of Sirmium. The paper will present a translation of this hagiography with explanatory notes, emphasising the likely sources of its origin and the analysis of the structure of the very appearance of bishop Irenaeus's suffering in the Ethiopian synaxarium.
\end{abstract}

Keywords: Saint Irenaeus, Sirmium, Ethiopian synaxarium. 